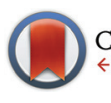

CrossMark \&lick for updates

Cite this: Dalton Trans., 2015, 44 14110

Received 14th May 2015, Accepted 27th June 2015 DOI: $10.1039 / \mathrm{c} 5 \mathrm{dt} 01817 \mathrm{j}$ www.rsc.org/dalton

\section{Spectroscopic, thermodynamic, kinetic studies and oxidase/antioxidant biomimetic catalytic activities of tris(3,5-dimethylpyrazolyl)borate $\mathrm{Cu}(ı)$ complexes $\uparrow$}

Shaban Y. Shaban, ${ }^{\star a}$ Abd El-Motaleb M. Ramadan, ${ }^{a}$ Mohamed M. Ibrahim, ${ }^{\text {a,b }}$ Mahmoud A. Mohamed ${ }^{b, c}$ and Rudi van Eldik*d,e

\begin{abstract}
A series of copper(I) complexes, viz. [Tp $\left.{ }^{\mathrm{MeMe}} \mathrm{Cu}(\mathrm{Cl})\left(\mathrm{H}_{2} \mathrm{O}\right)\right]$ (1), [Tp $\left.{ }^{\mathrm{MeMe}} \mathrm{Cu}(\mathrm{OAc})\left(\mathrm{H}_{2} \mathrm{O}\right)\right]$ (2), [Tp $\left.{ }^{\mathrm{MeMe}} \mathrm{Cu}\left(\mathrm{NO}_{3}\right)\right]$ (3) and $\left[\mathrm{Tp}^{\mathrm{MeMe}} \mathrm{Cu}\left(\mathrm{ClO}_{4}\right)\right]$ (4) containing tris(3,5-dimethylpyrazolyl)borate ( $\mathrm{KTp}^{\mathrm{MeMe}}$ ), have been synthesized and fully characterized. The substitution reaction of 1 with thiourea was studied under pseudofirst-order conditions as a function of concentration, temperature and pressure in methanol and acetonitrile as solvents. Two reaction steps that both depended on the nucleophile concentration were observed for both solvents. Substitution of coordinated methanol is about 40 times faster than the substitution of chloride. In acetonitrile, the rate constant for the displacement of coordinated acetonitrile was more than 20 times faster than the substitution of chloride. The reported activation parameters indicate that both reaction steps follow a dissociative mechanism in both solvents. On going from methanol to acetonitrile, the rate constant for the displacement of the solvent becomes more than 200 times faster due to the more labile acetonitrile, but the substitution mechanism remained to have a dissociative character. The antioxidant activities of 1-4 were evaluated for superoxide dismutase (SOD), glutathione-stransferase (GSTO and glutathione reduced (GSH-Rd) activity. 1 and $\mathbf{2}$ were found to show $(p<0.05)$ the highest antioxidant activity in comparison to $\mathbf{3}$ and $\mathbf{4}$, which can be ascribed to the geometric configuration as well as the nature of the co-ligand. 1 showed catechol oxidase activity with turnover numbers of $20 \mathrm{~min}^{-1}$ and a coordination affinity for 3,5-DTBC of $K_{1}=31 \mathrm{mM}^{-1} . K_{1}$ is rather large and seems to be typical for faster biomimetic models, and also for the enzyme itself $\left(25 \mathrm{mM}^{-1}\right)$. The reaction rate depended linearly on the complex concentration, indicating a first-order dependence on the catalyst concentration.
\end{abstract}

\section{Introduction}

In oxidative catalysis, transition metal complexes with polydentate ligands are often used since they feature structural and/or functional properties of non-heme enzymes. ${ }^{1}$ Copper-containing proteins are involved in various processes in living systems. ${ }^{2}$ The importance of copper ions as catalysts in both enzymatic $^{2}$ and non-enzymatic ${ }^{3}$ chemical systems is well

\footnotetext{
${ }^{a}$ Department of Chemistry, Faculty of Science, Kafrelsheikh University, Egypt. E-mail: shaban.shaban@sci.kfs.edu.eg

${ }^{b}$ Department of Chemistry, Faculty of Science, Taif University, Taif, Saudi Arabia ${ }^{c}$ Department of Biochemistry, Faculty of Agriculture, Cairo University, Cairo, Egypt ${ }^{d}$ Inorganic Chemistry, Department of Chemistry and Pharmacy, University of Erlangen-Nuremberg, Egerlandstr. 1, 91058 Erlangen, Germany. E-mail: rudi.vaneldik@fau.de

${ }^{e}$ Faculty of Chemistry, Jagiellonian University, 30-060 Krakow, Poland $\dagger$ Electronic supplementary information (ESI) available. See DOI: 10.1039/ c5dt01817j
}

known. Many copper proteins activate molecular oxygen, and the functions of these proteins vary; they serve as oxygen carriers (hemocyanin $)^{4}$ or as catalysts in oxygenation (oxygenases) or oxidation (oxidases) reactions. ${ }^{5}$

Catechol oxidase is present in the cell cytoplasm. ${ }^{6}$ If the plant tissues are damaged, catechol is released and the enzyme converts catechol to ortho-quinone, ${ }^{7}$ which is a natural antiseptic. Catechol oxidase, therefore, plays a role in plant defence mechanisms ${ }^{8}$ and helps to protect damaged plants against both bacterial and fungal diseases. It has been suggested that the quantity of catechol oxidase produced by a plant may be related to its susceptibility to fungal infection. Benzoquinone inhibits the growth of microorganisms and prevents damaged fruit from rotting. ${ }^{9}$

Significant understanding of the structural and the functional aspects of catechol oxidase has been obtained through studies on synthetic functional models. ${ }^{10}$ Though several dinuclear copper complexes successfully emulate the 
enzyme, ${ }^{11}$ both structurally and functionally, a large number of mononuclear copper complexes are also known to exhibit significant catecholase activity. ${ }^{12}$ The catalytic activity of the mononuclear complexes can be tailored by varying the geometric and steric properties around the metal centre, thus providing valuable opportunities to probe the structure-activity relationship in these model complexes. Several mechanistic and theoretical investigations have been reported for different binuclear catechol oxidase models, ${ }^{13}$ whereas the same for the mononuclear counterparts remain surprisingly rare. ${ }^{14}$ For this reason we became interested in studying the mononuclear model complexes.

Due to our overall objective to obtain a better understanding of various chemical and biological oxidation processes, we moved to synthetic small molecule modelling studies to obtain mechanistic insight on these reactions. In this regard, we recently reported the use of a series of $\mathrm{Cu}(\mathrm{II})$ complexes as functional mimics of catechol oxidase. ${ }^{15}$ Thus, to extend further on this, we set out to design new functional models containing tris(pyrazolyl)borate-copper derivatives that mimic catechol oxidase. The use of tris(pyrazolyl)borate-copper derivatives for modelling purposes has been reviewed. ${ }^{16}$ Tris(pyrazolyl)borate ligands have been applied owing to the fact that these anionic ligands take versatile coordination modes. ${ }^{17}$

Fujisawa et al. have synthesized a series of mono- and dinuclear copper(II) complexes containing the sterically demanding tris(3,5-dialkylpyrazolyl)borate. They have found that structural effects on the alkyl substituents at the 3-position in hydrotris(3,5-dialkylpyrazolyl)borates play an important role in modifying the coordination environment around the copper(II) centre and their physiochemical properties. ${ }^{18}$ Very recently, Harding et al. have synthesized copper(II) hydrotris (3,5-diphenylpyrazolyl)borate dithiocarbamate complexes, $\left[\mathrm{Tp}^{\mathrm{Ph} 2} \mathrm{Cu}(\mathrm{dtc})\right]\left(\mathrm{dtc}=\mathrm{S}_{2} \mathrm{CNEt}_{2}, \mathrm{~S}_{2} \mathrm{CNBz}_{2}\right.$ and $\left.\mathrm{S}_{2} \mathrm{CN}\left(\mathrm{CH}_{2}\right)_{4}\right)$, containing phenyl substituents in the 3 - and 5-position with the aim of mimicking green copper proteins. ${ }^{19}$ This prompted us to synthesize a series of copper(II) complexes containing the hydrotris(pyrazolyl)borates with small substituents such as methyl in the 3- and 5-position to investigate their physiochemical properties. We describe herein the synthesis of a series of copper(II) complexes, viz. [ $\left.\mathrm{Tp}^{\mathrm{MeMe}} \mathrm{Cu}(\mathrm{Cl})\left(\mathrm{H}_{2} \mathrm{O}\right)\right](\mathbf{1})$, $\left[\mathrm{Tp}^{\mathrm{MeMe}} \mathrm{Cu}(\mathrm{OAc})\left(\mathrm{H}_{2} \mathrm{O}\right)\right] \quad$ (2), $\quad\left[\mathrm{Tp}^{\mathrm{MeMe}} \mathrm{Cu}\left(\mathrm{NO}_{3}\right)\right] \quad$ (3) and $\left[\mathrm{Tp}^{\mathrm{MeMe}} \mathrm{Cu}\left(\mathrm{ClO}_{4}\right)\right]$ (4) containing tris(3,5-dimethylpyrazolyl)borate as $\mathrm{N}_{3}$ donor set. The nitrato copper(II) complex 3 has previously been reported, in which the nitrato ligand coordinates to the copper(II) centre in a bidentate fashion (see Discussion). ${ }^{20}$

In order to study the relevance of the geometric configuration around the $\mathrm{Cu}$ (II) centres in these complexes for the catalytic activity of the enzyme during the oxidation process in more detail, we used coordinated counter anions to occupy the in-plane position of the trigonal bipyramidal structure. A detailed kinetic study of the ligand substitution reaction as well as the catechol oxidase activity of $\mathbf{1}$ was performed to provide information pertinent to the understanding of the structure-reactivity correlation. Also the antioxidant activity of
1-4 was evaluated for peroxide dismutase (SOD), glutathione-stransferase (GST) and glutathione reduced (GSH-Rd), and correlated with their structures.

\section{Results and discussion}

\subsection{Characterization of the model complexes 1-4}

The $C_{3}$-symmetrical tripodal ligand $\mathrm{Tp}^{\mathrm{MeMe}}$ was used to emulate the $\left[\mathrm{N}_{3}\right]$ coordination environment provided by the three histidine protein residues in zinc enzymes and proved to be an organized template for building structural model complexes. $^{21}$ The synthesis of the $\mathrm{Cu}(\mathrm{II})$ complexes $\left[\mathrm{Tp}^{\mathrm{MeMe}} \mathrm{Cu}(\mathrm{Cl})\right.$ $\left.\left(\mathrm{H}_{2} \mathrm{O}\right)\right](\mathbf{1}),\left[\mathrm{Tp}^{\mathrm{MeMe}} \mathrm{Cu}(\mathrm{OAc})\left(\mathrm{H}_{2} \mathrm{O}\right)\right](2)$, and $\left[\mathrm{Tp}^{\mathrm{MeMe}} \mathrm{Cu}\left(\mathrm{ClO}_{4}\right)\right]$ (4), was carried out in absolute methanol by treating the ligand $\mathrm{KT}^{\mathrm{MeMe}}$ with equimolar amounts of the corresponding copper(II) salts under anaerobic conditions. The methyl substituent at the 3- and 5-positions of the pyrazolyl ring was found to be an essential requirement to stabilize the obtained complexes. The chemical analysis and some physical properties of the isolated pure $\mathrm{Cu}(\mathrm{II})$ complexes demonstrate that all the complexes have $(1: 1)$ copper(II) : ligand stoichiometry. The microcrystalline complexes are stable as solids under atmospheric conditions. The molar conductance values of the reported $\mathrm{Cu}$ (II) complexes were measured for $1 \mathrm{mM}$ solutions in DMF at room temperature. The results obtained demonstrate that these complexes are non-electrolytes, ${ }^{22}$ indicating that their counter anions are bound directly to the central $\mathrm{Cu}(\mathrm{II})$ ion.

2.1.1. Infrared spectra. The IR and Raman spectral data (see ESI Fig. S1 and $\mathrm{S} 2 \dagger$ ) of the ligand $\mathrm{KTp}^{\mathrm{MeMe}}$, providing valuable information regarding its coordinating sites to $\mathrm{Cu}$ (II) ions, are shown in Table 1. The formation of complexes 1-4 is evidenced by the presence of a B-H stretch near $2500 \mathrm{~cm}^{-1}$ in the infrared spectra of all complexes. The B-H stretch, which appears at $2436 \mathrm{~cm}^{-1}$ in the free $\mathrm{KTp}^{\mathrm{MeMe}}$ ligand shifts to higher energy in all complexes. A similar shift has previously been reported for $\mathrm{Tp}$ complexes of transition metals. ${ }^{23}$ The Raman spectrum of the ligand showed almost identical bands with those found in its IR spectrum, which also showed a characteristic band for this ligand system at a frequency of $2443 \mathrm{~cm}^{-1}$, which is assigned to $\nu(\mathrm{B}-\mathrm{H})$. Another main difference between the IR spectra of the free ligand and its complexes 1-4 (see ESI Fig. S3-S7†) is confined in the bands of $\nu(\mathrm{C}=\mathrm{N})$. This frequency is shifted by $19-36 \mathrm{~cm}^{-1}$ towards lower wave numbers in the IR spectra of all complexes com-

Table 1 Electronic absorption spectra of the $\mathrm{Cu}(\mathrm{II})$ complexes 1-4 in $\mathrm{CH}_{3} \mathrm{CN}$ solution

\begin{tabular}{lllll}
\hline Complex & $\begin{array}{l}\lambda\left(\mathrm{cm}^{-1}\right) \\
\mathrm{d}_{z^{2}} \rightarrow \mathrm{d}_{x^{2}-y^{2}}\end{array}$ & $\varepsilon\left(\mathrm{M}^{-1} \mathrm{~cm}^{-1}\right)$ & $\begin{array}{l}\lambda\left(\mathrm{cm}^{-1}\right) \\
\mathrm{d}_{x y} \rightarrow \mathrm{d}_{x^{2}-y^{2}}\end{array}$ & $\varepsilon\left(\mathrm{M}^{-1} \mathrm{~cm}^{-1}\right)$ \\
\hline $\mathbf{1}$ & 12987 & 30.0 & 21978 & 220.0 \\
$\mathbf{2}$ & 13615 & 28.0 & 2222 & 280.0 \\
$\mathbf{3}$ & 14321 & 27.0 & 23905 & 35.0 \\
$\mathbf{4}$ & 14705 & 20.0 & 23809 & 40.0
\end{tabular}



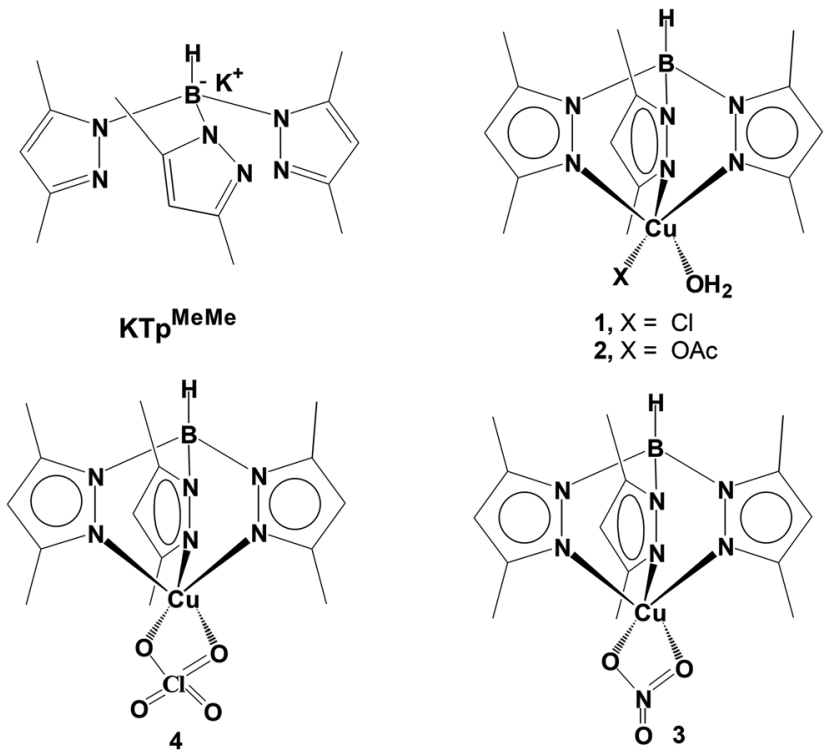

Scheme 1 Proposed structures of the ligand tris(3,5-dimethylpyrazolyl)borate (KTp ${ }^{\mathrm{MeMe}}$ ) and the model complexes 1-4.

pared to that of the free ligand, thus indicating coordination to $\mathrm{Cu}(\mathrm{II})$ through the three pyrazolyl nitrogen atoms (Scheme 1). This mode of bonding to $\mathrm{Cu}$ (II) ion is further supported by the appearance of a new absorption band at 429-436 $\mathrm{cm}^{-1}$, which is not observed in the spectrum of the free ligand. This band is assignable to $\nu(\mathrm{M}-\mathrm{N}){ }^{24}$ For the chloro complex $\mathbf{1}$, the non-electrolytic chloride ion exhibits an absorption band characteristic of a terminally coordinated chloride ion. ${ }^{25}$ The vibration mode of the acetate group in complex 2 at $1559 \mathrm{~cm}^{-1}$ can be assigned to a unidentate acetate anion. ${ }^{22}$ This finding is further confirmed by the appearance of a new absorption band at $570 \mathrm{~cm}^{-1}$, which is characteristic for $\nu(\mathrm{M}-\mathrm{O}) .{ }^{26}$ On the other hand, the molar conductivity measurements demonstrated that the acetato complex behaves as a 1:1 electrolyte. The IR spectrum of the perchlorato complex 4 shows very intense absorption bands at 1095 and $623 \mathrm{~cm}^{-1}$, indicating the coordination of the perchlorate counter anion most probably in a bidentate mode. In this case, complex 4 most probably has a five-coordinate $\mathrm{Cu}$ (II) centre. In the $\mathrm{OH}$ stretching region, a very broad absorption extending from about 3320 to $3350 \mathrm{~cm}^{-1}$ is detected for the coordinated water molecules in the case of the chloro and acetato complexes. $^{26}$

2.1.2. Electronic absorption spectra. The electronic absorption spectra of the newly synthesized $\mathrm{Cu}$ (II) complexes 1-4 were recorded in $\mathrm{CH}_{3} \mathrm{CN}$ solution and are all very similar (see Table 1 and ESI Fig. S11 and S12†). Two weak peaks appearing in the low energy visible region at 12 987-14 705 and 21978-23 $905 \mathrm{~cm}^{-1}$ are assignable to d-d transitions of the $\mathrm{Cu}(\mathrm{II})$ ion in a square-pyramidal environment. ${ }^{27}$ In the square-pyramidal $\mathrm{Cu}(\mathrm{II})$ complexes the plausible d-orbital energy level scheme (idealized symmetry group $C_{4 \mathrm{v}}$ ) is $\mathrm{d}_{x^{2}-y^{2}}>$ $\mathrm{d}_{z^{2}}>\mathrm{d}_{x y}>\mathrm{d}_{x z}, \mathrm{~d}_{y z}$. Accordingly, the higher energy band of the $\mathrm{d}-\mathrm{d}$ transitions can be assigned to $\mathrm{d}_{x y} \rightarrow \mathrm{d}_{x^{2}-y^{2}}$ and the lower energy band to $\mathrm{d}_{z^{2}} \rightarrow \mathrm{d}_{x^{2}-y^{2}}$. The other $\mathrm{d}-\mathrm{d}$ bands are probably masked by the more intense band of the charge transfer or internal ligand transitions. These spectral parameters are consistent with other $\mathrm{Cu}(\mathrm{II})$ complexes in the five-coordinate square-pyramidal stereochemistry. ${ }^{28,29}$

2.1.3. EPR spectra and magnetic moment studies. The room temperature magnetic moments and details of the polycrystalline EPR spectra of the studied $\mathrm{Cu}(\mathrm{II})$ complexes are listed in Table 2 (see ESI Fig. S13-S16†). The magnetic moment values of these $\mathrm{Cu}(\mathrm{II})$ complexes are in the 1.82-1.96 BM range, indicating the presence of magnetically dilute $\mathrm{Cu}(\mathrm{II})$ complexes. $^{30}$ As indicated by these values in Table 2, it seems that no spin-exchange interaction between $\mathrm{Cu}(\mathrm{II})$ ions exists in the polycrystalline state of these chelates. This fact is also supported by the EPR spectra of complexes 3 and 4 which give $G$-values of 4.563 and 4.952 (Table 2) since $\left[G=\left(g_{||}-2\right) /\left(g_{\perp}-2\right)\right]>4.0 .^{31}$ These $G$-values indicate that the local tetragonal axes are aligned parallel or only misaligned. ${ }^{32}$

For the five-coordinate complexes 1 and 2, square-pyramidal or trigonal bipyramidal geometry can be considered. The spectral features of these complexes are similar and exhibit intense EPR signals that are characteristic of the rhombic symmetry with three $g$-values. These observed $g$-values $\left(g_{3}, g_{2}\right.$, and $g_{1}$ in order of decreasing magnitude) were computed from the spectra. Square-pyramidal and trigonal bipyramidal geometry are characterized by $\mathrm{d}_{x^{2}-y^{2}}$ and $\mathrm{d}_{z^{2}}$ in the ground states, respectively. ${ }^{29}$ For systems with $g_{3}>g_{2}>g_{1}$, the ratio of $\left(g_{3}-g_{2}\right) /\left(g_{2}-\right.$ $\left.g_{1}\right)=R$ is useful to distinguish the geometry. If the ground state is $\mathrm{d}_{z^{2}}$, the value of $R$ is larger than 1 ; when the ground state is predominantly $\mathrm{d}_{x^{2}-y^{2}}$, the value of $R$ is less than 1 . The chloro and acetato complexes under study show values of $R$ (Table 2) less than 1, and these results confirm a five-coordinate, square-pyramidal geometry.

The EPR spectra of complexes 3 and $\mathbf{4}$ have the same features and show an axial signal in the solid state with poorly resolved hyperfine structure. The $g_{\|}$and $g_{\perp}$ values are greater than 2.0023, which indicates that the $\mathrm{Cu}$ (II) ion is present in an axial symmetry with all the principal axes aligned parallel. Complex 3 has been previously reported ${ }^{33}$ and its X-ray single crystal structure demonstrated a five-coordinate square-pyramidal environment around the $\mathrm{Cu}$ (II) centre. Due to the great similarity between complexes $\mathbf{3}$ and $\mathbf{4}$, we suggest that complex 4 also has a five-coordinate square-pyramidal geometry. This

Table 2 Magnetic moment values and EPR spectral data for the $\mathrm{Cu}(\Perp)$ complexes 1-4

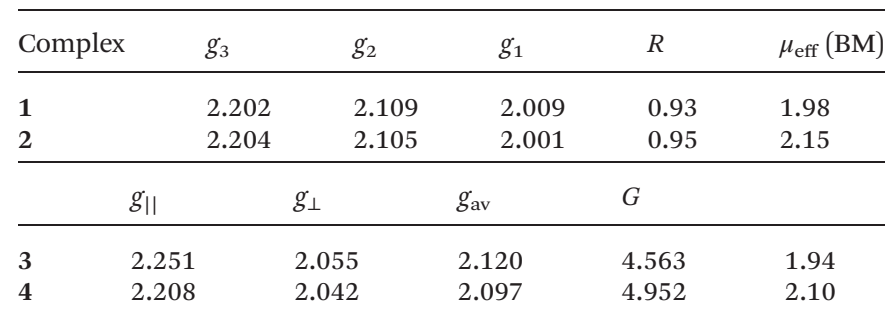


Table 3 Kinetic and thermodynamic parameters for the thermal behaviour of the Cu(I) complexes 1-3 (see ESI Fig. S8-S10)

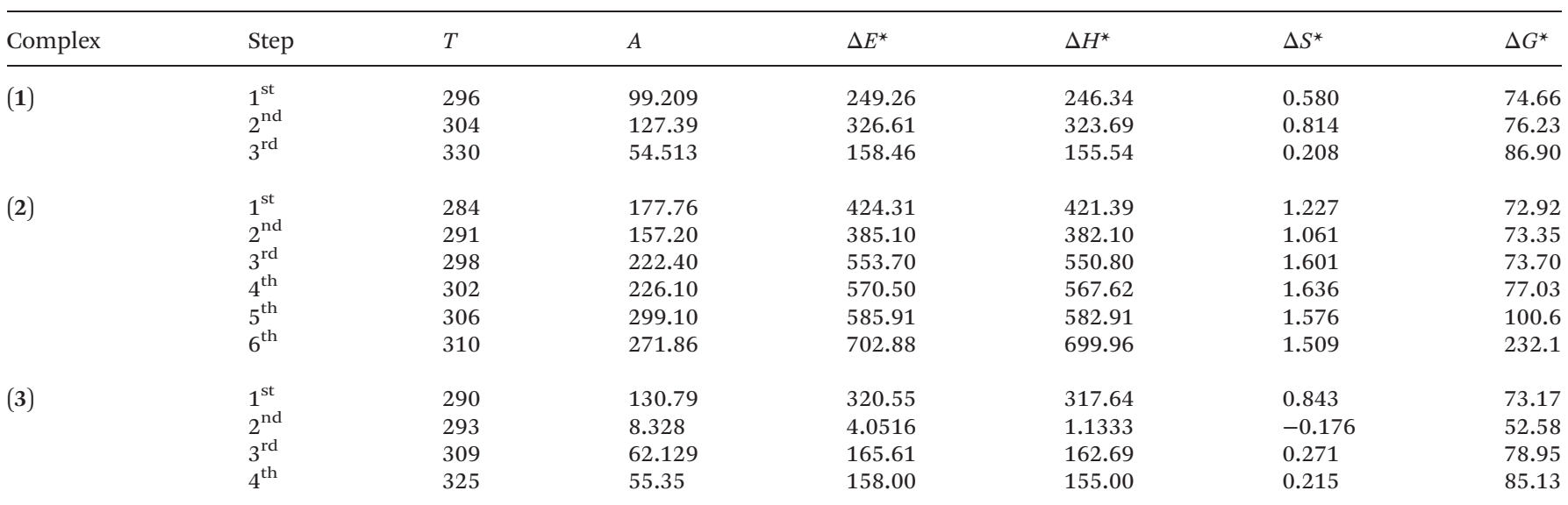

hypothesis finds support from the IR spectrum which confirms the bidentate fashion for coordination of the $\mathrm{ClO}_{4}{ }^{-}$ counter anion. A five-coordinate $\mathrm{Cu}(\mathrm{II})$ complex may possess two geometries, viz. trigonal bipyramidal or square pyramidal, which are characterized by the ground states $\mathrm{d}_{x^{2}-y^{2}}$ or $\mathrm{d}_{z^{2}}$, respectively. The EPR spectra provide an excellent basis to distinguish between these two ground states. The trend $g_{\|}>g_{\perp}>$ 2.0023 , indicates that the unpaired electron lies predominantly in $\mathrm{d}_{x^{2}-y^{2}}$ while the trend $g_{\perp}>g_{\|}>2.0023$ indicates that the ground state is $\mathrm{d}_{z^{2}}$. For complexes 3 and 4 the observed trend of $g$-values is $g_{\| \mid}>g_{\perp}>2.0023$ and indicates that the unpaired electron lies predominantly in the $\mathrm{d}_{x^{2}-y^{2}}$ orbital. These spectral features are characteristic for the square-pyramidal stereochemistry in accordance with the previously reported X-ray structural analysis of complex $3 .{ }^{33}$

2.1.4. Thermal analysis. The TG-DTG curve of the chloro $\mathrm{Cu}$ (II) complex 1 revealed the following steps: (i) The initial weight loss in the temperature ranges 175-320 and $185-290{ }^{\circ} \mathrm{C}$, is ascribed to the elimination of one coordinated water molecule, the chloro ligand and approximately $80 \%$ of the organic part, respectively. The further decomposition of the organic moiety in the final degradation step yields $\mathrm{CuO}$ (found $19.64 \%$; calc. $19.08 \%$ ) as final product. The thermal decomposition pattern of the acetato complex 2 displays five steps of weight loss: (i) The initial weight loss in the range ${ }^{150}-260{ }^{\circ} \mathrm{C}$ is attributed to the removal of both the coordinated water and acetate ligands, as well as $80 \%$ of the organic part of the ligand system, with weight loss of $80.23 \%$ (exp.) and $80.04 \%$ (theor.); (ii) The final decomposition step comprises the complete removal of the organic residual in the temperature range $280-390{ }^{\circ} \mathrm{C}$ and formation of the metal oxide $\mathrm{CuO}$ (found 19.77\%; calc. 19.12\%) as final thermal decomposition product. For all complexes, the copper content determined from the residual metal oxide residual was found to be in satisfactory agreement with the values calculated on the basis of the suggested composition formula based on the elemental analysis data.

The stability of the obtained $\mathrm{Cu}(\mathrm{II})$ complexes were investigated kinetically by using the Coats-Redfern approach. ${ }^{34}$ The results are listed in Table 3 . The higher values of the activation energies for the elimination of coordinated water and chlorine atoms in the first step of the decomposition process indicate that they are coordinated to the copper. The relatively high values for the subsequent decomposition steps indicate that the organic part of the ligand are strongly coordinated to the $\mathrm{Cu}$ (II) ions. The negative entropy values for the second and other subsequent steps indicate that the activated complex has a more ordered structure than the reactants. ${ }^{35}$ This also indicates that the chloro $\mathrm{Cu}(\mathrm{II})$ complex 1 has a higher thermal stability than the other complexes.

\subsection{Kinetic studies on ligand substitution reactions}

Ealier studies on $\mathrm{Cu}(\mathrm{II})$ catecholase functional models demonstrated that the exchange reaction between the catecholase and a good leaving group in the coordination sphere of the complex initiates the catalytic oxidation cycle. If the coordinated groups are stronger nucleophiles than the catecholate anion, no oxidation will be observed for the fivecoordinate $\mathrm{Cu}$ (II) catecholase models. The fifth ligand must be released before coordination of the catecholate anion to the copper ion and association with oxygen during the catalytic oxidation cycle can occur. To further elucidate the biomimetic catalytic activity of the $\mathrm{Cu}$ (II) catecholase model 1, a detailed kinetic study on ligand substitution reactions was performed with thiourea (TU) as entering nucleophile. Thiourea was selected because of its high nucleophilicity that will prevent the back reaction with chloride or solvent. Furthermore, it was selected as a neutral entering ligand such that the overall reaction is accompanied by charge creation, and the formation of the transition state may involve changes in dipole moment. This will affect the activation parameters, especially the entropy and volume of activation, when the reaction is studied in different solvents.

Two solvents, viz. methanol and acetonitrile, were selected for this study due to the limited solubility of complex $\mathbf{1}$. The UV-Vis spectra of complex 1 turned out to be significantly different in these solvents (see typical spectra recorded during the kinetic measurements reported below), which is ascribed 
to the displacement of coordinated water by methanol and acetonitrile in these solvents, respectively. The possible formation of a four-coordinate species could be eliminated because the dissociation of the coordinated solvent played an important role in the studied substitution reactions (see below).

Reactions of 1 with thiourea can be monitored kinetically around $380 \mathrm{~nm}$. Solutions were prepared by dissolving known amounts of $\mathbf{1}$ in methanol. The substitution reactions were studied as a function of TU concentration, temperature and pressure. Fig. 1 shows UV/Vis spectral changes and a representative kinetic trace.

Rate constants for the reactions were determined by using total TU concentrations in the range $0.1-1.0 \mathrm{M}$, i.e. always in a large excess over the $\mathrm{Cu}(\mathrm{II})$ complex concentration. Throughout the nucleophile concentration range it was possible to fit the absorbance/time traces to a two-exponential function:

$$
A=a_{1} e^{-k_{\mathrm{obsd} 1} t}+a_{2} e^{-k_{\mathrm{obsd} 2} t}+A_{0}
$$

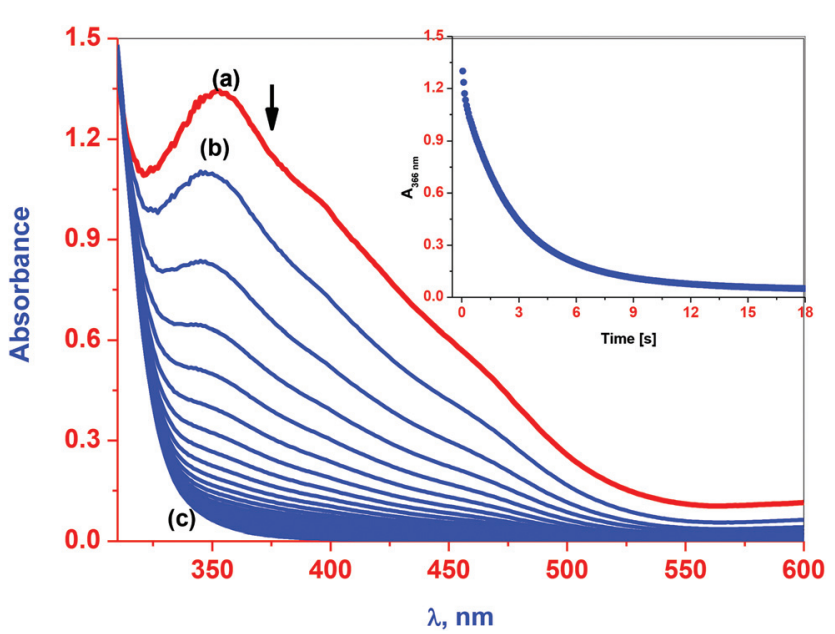

Fig. 1 UV/Vis spectral changes recorded for the reaction of complex 1 $(1 \mathrm{mM})$ with thiourea $(0.1 \mathrm{M})$ in methanol at $296 \mathrm{~K}$ : (a) spectrum before the reaction; (b) spectrum obtained several milliseconds after mixing of the reactants in the stopped-flow apparatus; (c) spectrum obtained after $18 \mathrm{~s}$ (inset: Representative kinetic trace obtained at $380 \mathrm{~nm}$, solid line was obtained by fitting the data to a two-exponential function).
The overall kinetic trace is biphasic and is in line with that reported for related complexes. ${ }^{15 a, 36}$ An initial fast reaction (rate constant $k_{\text {obsd1 }}$ ) is followed by a much slower one (rate constant $\left.k_{\text {obsd2 }}\right)$. $k_{\text {obsd1 }}$ increases linearly with TU concentration (Fig. 2), which leads to the second-order rate constant $k_{1}=7.2 \pm 0.3 \mathrm{M}^{-1} \mathrm{~s}^{-1}$. Rate constant $k_{\mathrm{obsd} 2}$ also depends linearly on the TU concentration with second-order rate constant $k_{2}=0.18 \pm 0.01 \mathrm{M}^{-1} \mathrm{~s}^{-1}$ at $296 \mathrm{~K}$ (Fig. 2).

The observed kinetic behaviour can be accounted for in terms of two subsequent substitution reactions (1) and (2) in which the methanol and chloride ligands are displaced by TU, characterized by the second-order rate constants $k_{1}$ and $k_{2}$, respectively.

$$
\left[\mathrm{Cu}^{\mathrm{II}}(\mathrm{L})(\mathrm{MeOH}) \mathrm{Cl}\right]^{0}+\mathrm{TU} \rightarrow\left[\mathrm{Cu}^{\mathrm{II}}(\mathrm{L})(\mathrm{TU}) \mathrm{Cl}\right]^{0}+\mathrm{MeOH} \quad k_{1}
$$

$$
\left[\mathrm{Cu}^{\mathrm{II}}(\mathrm{L})(\mathrm{TU}) \mathrm{Cl}\right]^{0}+\mathrm{TU} \rightarrow\left[\mathrm{Cu}^{\mathrm{II}}(\mathrm{L})(\mathrm{TU})_{2}\right]^{+}+\mathrm{Cl}^{-} \quad k_{2}
$$

It follows from this reaction scheme that $k_{\mathrm{obs} 1}$ and $k_{\mathrm{obs} 2}$ should depend linearly on the entering TU concentration in the absence of a back reaction as shown in Fig. 2, such that $k_{\text {obs } 1}=k_{1}[\mathrm{TU}]$ and $k_{\text {obs2 }}=k_{2}[\mathrm{TU}]$. The rate constants in Table 4 show that the second substitution reaction is about 40 times slower than the first one. This can be ascribed to the difference in the lability of methanol and chloride during their displacement by thiourea.

Since activation parameters such as $\Delta S^{\#}$ and $\Delta V^{\#}$ are sensitive probes that reflect the nature of the transition state of a given reaction, their determination can serve as a useful mechanistic tool in assigning the mechanism of a substitution reaction. The temperature and pressure dependences of the substitution rate constants were studied by stopped-flow techniques in the temperature range 8.5 to $28.0{ }^{\circ} \mathrm{C}$ and pressure range 10 to $150 \mathrm{MPa}$, respectively. The observed temperature and pressure dependencies are presented in Fig. 3 and 4, respectively, and the plots are linear over the ranges studied. From these plots the activation parameters for the TU substitution reactions were estimated, and the data are summarized in Table 4 . The values of $\Delta S^{\#}$ and $\Delta V^{\#}$ are positive and support the operation of a dissociative $(D)$ or interchange dissociative
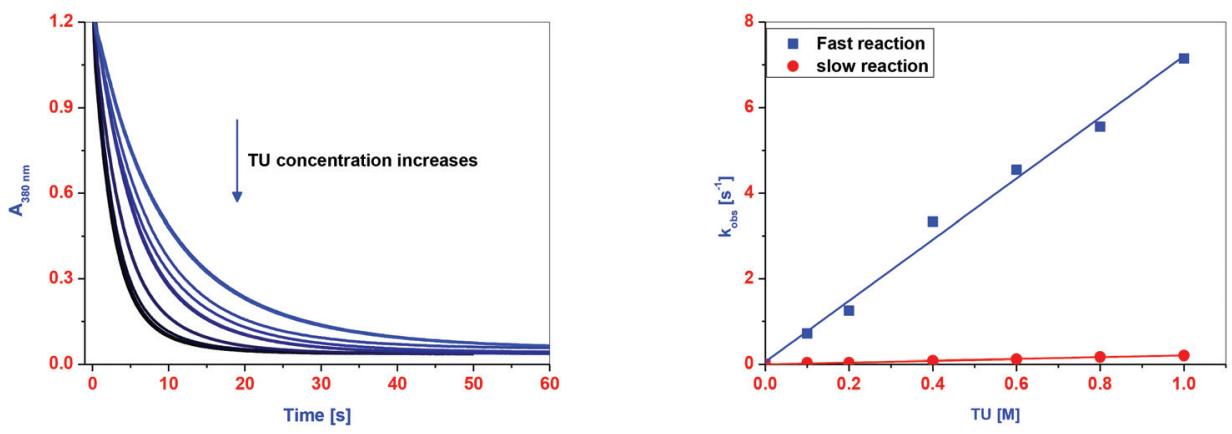

Fig. 2 Plots of $k_{\mathrm{obsd}} v s$. thiourea (TU) concentration for complex 1 in methanol at $296 \mathrm{~K}$ ( $\square$ : fast reaction step; $\bullet$ : slow reaction step). Experimental conditions: [1] = $1 \mathrm{mM}$, wavelength $355 \mathrm{~nm}$. 
Table 4 Rate constants and activation parameters for the reaction of the $\mathrm{Cu}(\mathrm{II})$ complex 1 with TU in both methanol and acetonitrile

\begin{tabular}{|c|c|c|c|c|}
\hline \multirow{2}{*}{$\begin{array}{l}\text { Rate constants } \\
\text { and activation } \\
\text { parameters }\end{array}$} & \multicolumn{2}{|c|}{$\mathrm{MeOH}$ at $380 \mathrm{~nm}$} & \multicolumn{2}{|c|}{$\mathrm{CH}_{3} \mathrm{CN}$ at $340 \mathrm{~nm}$} \\
\hline & $1^{\text {st }}$ step & $2^{\text {nd }}$ step & $1^{\text {st }}$ step & $2^{\text {nd }}$ step \\
\hline$k$ at $296 \mathrm{~K}\left[\mathrm{M}^{-1} \mathrm{~s}^{-1}\right]$ & $7.2 \pm 0.3$ & $0.18 \pm 0.01$ & $96 \pm 2$ & $5.2 \pm 0.2$ \\
\hline$\Delta H^{\#}\left[\mathrm{~kJ} \mathrm{~mol}^{-1}\right]$ & $86 \pm 9$ & $80 \pm 1$ & $89 \pm 10$ & $89 \pm 2$ \\
\hline$\Delta S^{\#}\left[\mathrm{~J} \mathrm{~K}^{-1} \mathrm{~mol}^{-1}\right]$ & $+64 \pm 20$ & $+15 \pm 4$ & $+87 \pm 30$ & $+70 \pm 6$ \\
\hline $\begin{array}{l}\Delta V^{\#} \text { at } 296 \mathrm{~K} \\
{\left[\mathrm{~cm}^{3} \mathrm{~mol}^{-1}\right]}\end{array}$ & $+10 \pm 1$ & $+13.5 \pm 0.6$ & $+23.7 \pm 0.9$ & $+24.7 \pm 0.9$ \\
\hline
\end{tabular}

$\left(I_{\mathrm{d}}\right)$ mechanism for reactions (1) and (2). ${ }^{37,38}$ The magnitude of the $\Delta V^{\#}$ data is such that it favours more an $I_{\mathrm{d}}$ mechanism, i.e. concerted bond breakage with the leaving group and bond formation with the entering nucleophile (see further Discussion).

Bulky tripodal ligands occupy more space around a metal centre and can block the incoming ligand trying to access a coordination site on the metal. The steric bulk of the tripodal ligand is thought to weaken the $\mathrm{Cu}-(\mathrm{MeOH} / \mathrm{Cl})$ bonds, thereby favouring ligand dissociation required to form the catalytically active species. In this case the $\mathrm{MeOH}$ ligand is the one that dissociates first, coordinates thiourea and forms a neutral complex. In a parallel step, the chloride ligand dissociates much slower to form a cationic dithiourea complex. The three tripodal arms donate enough electron-density to the $\mathrm{Cu}$ (II) centre to enable the dissociation of $\mathrm{Cl}^{-}$.

The kinetic behaviour of the reaction of complex 1 with thiourea was also investigated in acetonitrile in order to correlate the results with those found for methanol. The substitution reactions were studied as a function of TU concentration, temperature and pressure at $340 \mathrm{~nm}$. Fig. 5 shows UV/Vis spectral changes and a representative kinetic trace. As was seen in methanol, the overall reaction in acetonitrile is also biphasic with an initial fast reaction (rate constant $k_{\text {obsd1 }}$ ) followed by a slow one (rate constant $k_{\text {obsd2 }}$ ). $k_{\text {obsd1 }}$ increases linearly with TU concentration (Fig. 6), which leads to a second-order rate constant $k_{1}=96.0 \pm 2.0 \mathrm{M}^{-1} \mathrm{~s}^{-1}$. Rate constant $k_{\mathrm{obsd} 2}$ also depends linearly on the TU concentration with a second-order rate constant $k_{2}=5.2 \pm 0.2 \mathrm{M}^{-1} \mathrm{~s}^{-1}$ (Fig. 6).

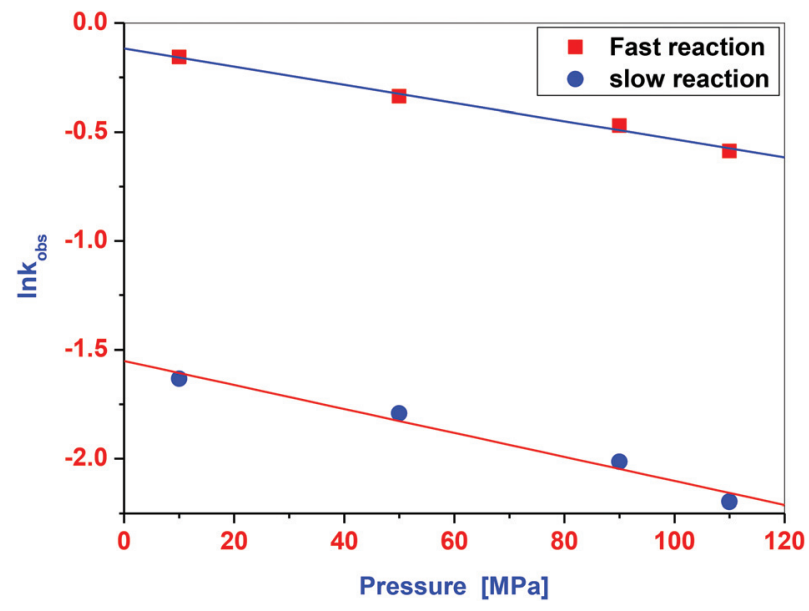

Fig. 4 Plots of $\ln k_{\text {obs }}$ vs. pressure for the reaction of the complex 1 with thiourea in methanol (घ: fast reaction step; $\bullet$ : slow reaction step). Experimental conditions: [1] $=0.1 \mathrm{mM},[\mathrm{TU}]=0.1 \mathrm{M}, 296 \mathrm{~K}$ and $355 \mathrm{~nm}$.

The rate constants and activation parameters such as $\Delta S^{\#}$ and $\Delta V^{\#}$ in Table 4 and Fig. 7 and 8 show that in acetonitrile: (i) the second-order rate constants $k_{1}=96.0 \pm 2.0 \mathrm{M}^{-1} \mathrm{~s}^{-1}$ and $k_{2}=5.2 \pm 0.2 \mathrm{M}^{-1} \mathrm{~s}^{-1}$ are much larger than in methanol due to the more labile coordinated acetonitrile solvent and the solvation of the $\mathrm{Cl}^{-}$leaving group in the transition state of the slow step; (ii) the second substitution reaction with thiourea is about 20 times slower than the first one; (iii) both reaction steps follow a dissociative $(D)$ mechanism due to the significantly more positive $\Delta V^{\#}$ values found for the release of acetonitrile compared to methanol.

By way of comparison, there are several reports in the literature on solvent exchange reactions of five-coordinate complexes of the type $[\mathrm{Cu}(\mathrm{L})(\text { solvent })]^{2+}, \mathrm{L}=$ tris(methylpyridine)amine and tris(aminoethyl)amine (tren), solvent $=\mathrm{H}_{2} \mathrm{O}$ and MeCN, for which activation volume data clearly support the operation of an associative interchange $I_{\mathrm{a}}$ mechanism. $^{39}$ However, on increasing the steric hindrance on the tren ligand and using DMF as solvent, the solvent exchange reaction on $\left[\mathrm{Cu}\left(\mathrm{Me}_{6} \text { tren }\right)(\mathrm{DMF})\right]^{2+}$ becomes extremely slow and proceeds
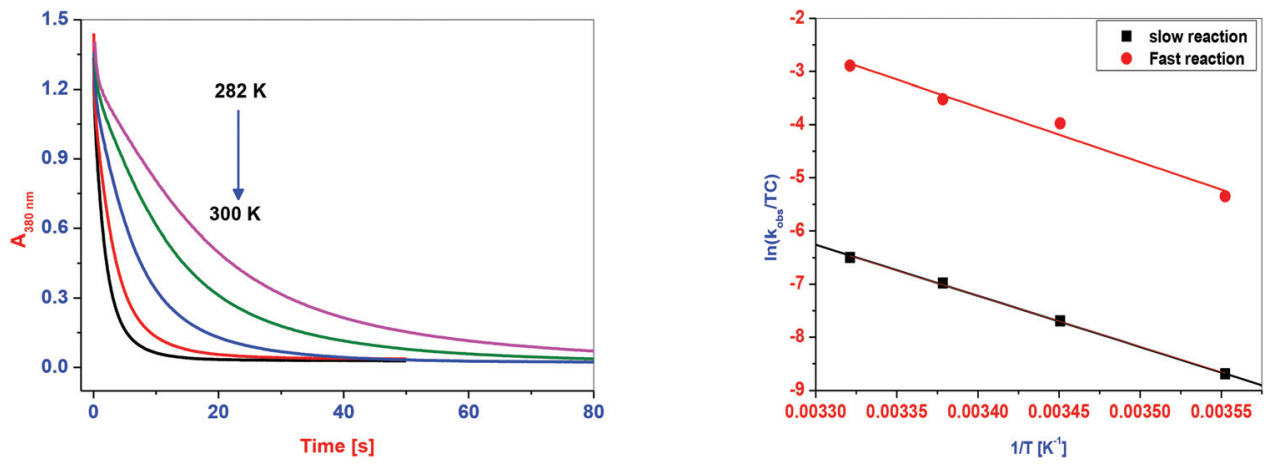

Fig. 3 Eyring plots for the determination of the activation enthalpy and entropy for the two reaction steps of complex 1 with thiourea in methanol (-: fast reaction step; : slow reaction step). Experimental conditions: $[1]=1 \mathrm{mM}$, $[T U]=0.1 \mathrm{M}$ and at $\lambda=355 \mathrm{~nm}$. (Temperature from $8.1-28.5^{\circ} \mathrm{C}$ ). 


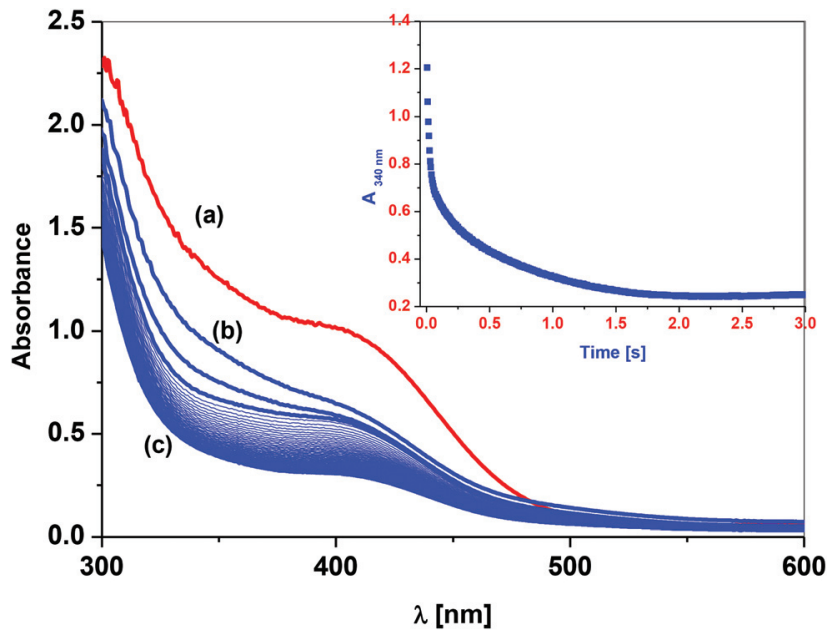

Fig. 5 UV/Vis spectral changes recorded for the reaction of complex 1 $(1 \mathrm{mM})$ with thiourea $(0.1 \mathrm{M})$ in acetonitrile at $296 \mathrm{~K}$ : (a) spectrum before the reaction; (b) spectrum obtained several milliseconds after mixing of the reactants in the stopped-flow (inset: Representative kinetic trace obtained at $340 \mathrm{~nm}$, solid line was obtained by fitting the data to a twoexponential function).

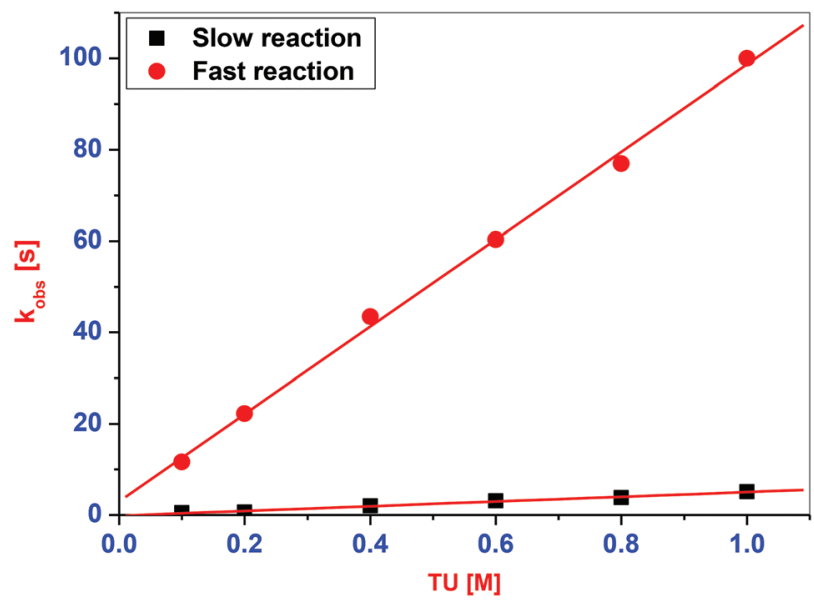

Fig. 6 Plots of $k_{\text {obsd }} v s$. thiourea concentration for the reaction with complex 1 in acetonitrile at $296 \mathrm{~K}$ (-) fast reaction step; $\mathbf{\square}$ : slow reaction step). Experimental conditions: [1] $=1 \mathrm{mM}$, wavelength $340 \mathrm{~nm}$.

according to a dissociative interchange $I_{\mathrm{d}}$ mechanism. ${ }^{39}$ We strongly believe that the steric hindrance on the tripodal tris(3,5-dimethylpyrazolyl)borate chelate in the present study is responsible for the dissociative nature $\left(I_{\mathrm{d}}\right.$ or $\left.D\right)$ of the investigated substitution reactions and prevents the operation of an associative interchange mechanism.

From all the above information, we can conclude that the solvent does not affect the nature of the mechanism but only the value of the rate constants and activation parameters. The difference in reactivity in both solvents can therefore be understood in term of: (1) The coordination ability of the solvent can often affect the reaction mechanism since the presence of lone

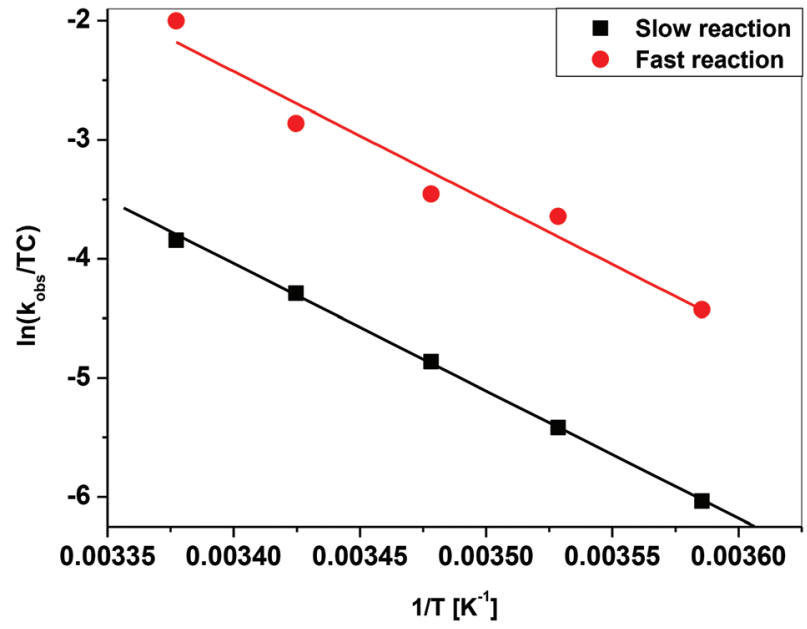

Fig. 7 Eyring plots for the determination of the activation enthalpy and entropy for the two reaction steps of complex 1 with thiourea in acetonitrile (-: fast reaction step; $\mathbf{-}$ : slow reaction step). Experimental conditions: [1] $=1 \mathrm{mM},[\mathrm{TU}]=0.1 \mathrm{M}$, Temperature $279-296 \mathrm{~K}$ and $340 \mathrm{~nm}$.

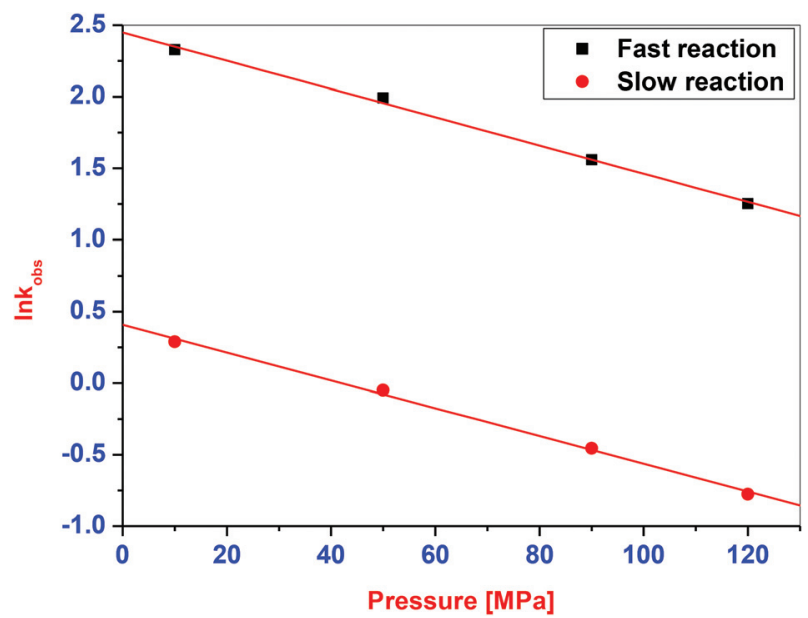

Fig. 8 Pressure dependence of the reaction of complex 1 with thiourea in acetonitrile ( $\square$ : fast reaction step; : slow reaction step). Experimental conditions: $[1]=0.1 \mathrm{mM},[\mathrm{TU}]=0.1 \mathrm{M}, 296 \mathrm{~K}$ and $340 \mathrm{~nm}$.

pairs and electron-rich donor atoms on the solvent can make it to be a stronger nucleophile; (2) the polarity of the solvent can also have an impact on the reaction rate since polar solvents usually favour reactions that involve charged species. Thus, in the present case we ascribe the observed effects to the difference in the nucleophilicity of the solvent, i.e. the donor strength of the coordinated solvent.

\subsection{Catechol oxidase mimetic activity}

In most of the catechol oxidase like catalytic activity studies of synthetic model complexes, 3,5-di-tert-butylcatechol (3,5DTBC) has been employed as substrate. Owing to its low redox potential, the substrate is readily oxidized and the bulky substituents prevent further reactions such as ring-opening pro- 
cesses. The product 3,5-di-tert-butyl-o-quinone (3,5-DTBQ), is quite stable and has a strong absorption at $\lambda_{\max }=400 \mathrm{~nm}$. Therefore, activities and reaction rates can be determined using electronic spectroscopy by following the appearance of the absorption maximum of the quinone. Reactivity and kinetic studies were performed in methanol because of the good solubility of the complex, the substrate (3,5-DTBC) and its product (3,5-DTBQ) in this solvent. Prior to a detailed kinetic study, it was first necessary to estimate approximately the ability of complex 1 to oxidize 3,5-DTBC. For this purpose, $0.1 \mathrm{mM}$ solution of 1 in methanol was treated with $100 \mathrm{mM}$ of 3,5-DTBC in the presence of air. The course of the reaction was followed by UV/VIS spectroscopy over the first $100 \mathrm{~min}$. The results indicated that complex $\mathbf{1}$ showed catechol oxidase activity with a turnover number of $20 \mathrm{~min}^{-1}$.

To determine the dependence of the observed reaction on the substrate concentration, solutions of $\mathbf{1}$ were treated with different concentrations of 3,5-DTBC in methanol. A first-order dependence on the substrate concentration was observed at low concentrations of 3,5-DTBC. At higher substrate concentrations, saturation kinetics was observed (see Fig. 9). The irreversible conversion into the quinone product is considered to be the ratedetermining step, i.e. $k_{2} \ll k_{-1}$ and $K_{1}=k_{1} / k_{-1}$. Although a much more complicated mechanism may be involved, the results show that this simple model is sufficient for a kinetic description. The rate law for the reaction sequence in (3) is given by (4):

$$
\begin{gathered}
\mathrm{Cu}^{\mathrm{II}} \text { complex }+3,5 \text {-DTBC } \underset{k_{-1}}{\stackrel{k_{1}}{\rightleftharpoons}} \mathrm{Cu}^{\mathrm{II}}-\mathrm{DTBC} \text {-adduct } \\
\underset{\mathrm{O}_{2}}{\frac{\mathrm{O}_{2}}{\longrightarrow}} \mathrm{Cu}^{\mathrm{II}} \text { complex }+ \text { DTBQ } \\
V=\frac{\mathrm{d}[\mathrm{DTBQ}]}{\mathrm{d} t}=k_{2}\left[\mathrm{Cu}^{\mathrm{II}} \text { complex-adduct }\right] \\
=\frac{k_{2} K_{1}\left[\mathrm{Cu}^{\mathrm{II}} \text { complex }\right][3,5-\mathrm{DTBC}]}{1+K_{1}[3,5-\mathrm{DTBC}]}
\end{gathered}
$$

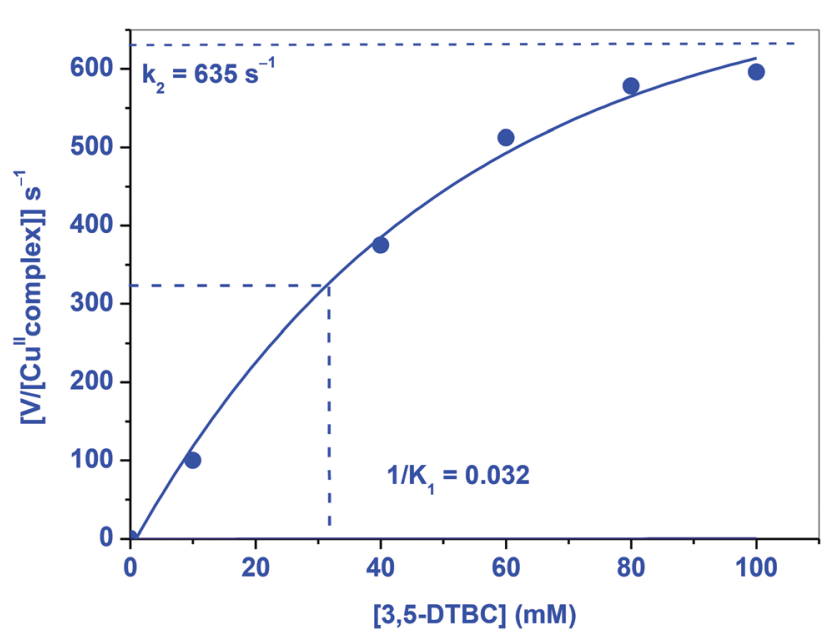

Fig. 9 Dependence of the initial rate of the oxidation reaction of 3,5DTBC on the concentration of the substrate 3,5-DTBC catalyzed by complex 1 in methanol. The concentration of 1 was $0.5 \times 10^{-4} \mathrm{M}$ and the reaction was followed at $400 \mathrm{~nm}$.

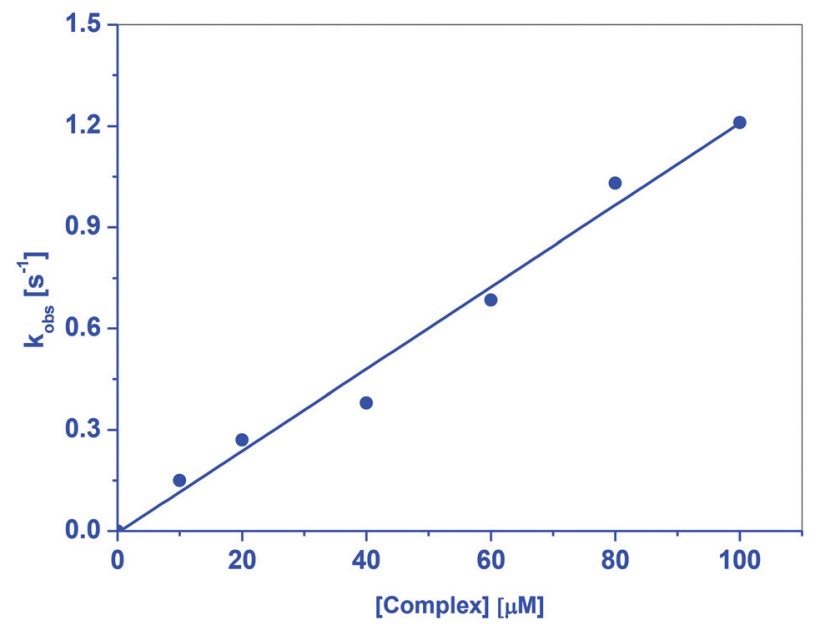

Fig. 10 Complex concentration dependence of the oxidation of catechol by the complex 1.

where $V$ is the rate of product formation, which can be rewritten as:

$$
\frac{V}{\left[\mathrm{Cu}^{\mathrm{II}} \text { complex }\right]}=\frac{k_{2} K_{1}[3,5-\mathrm{DTBC}]}{1+K_{1}[3,5-\mathrm{DTBC}]}
$$

The maximum rate constant, $k_{2}$, is reached when the catalyst is completely saturated with 3,5-DTBC, i.e. at high [3,5DTBC $]$. At a $V /\left[\mathrm{Cu}^{\mathrm{II}}\right.$ complex $]$ value of $k_{2} / 2$, the $[3,5-\mathrm{DTBC}]=$ $1 / K_{1}$, which according to Fig. 9 results in $K_{1}$, the coordination affinity of 3,5 -DTBC, $=k_{1} / k_{-1}=31 \mathrm{mM}^{-1} . K_{1}$ is rather large and seems to be typical for faster models as for the enzyme itself $\left(25 \mathrm{mM}^{-1}\right) .{ }^{40}$ The reaction rate depends linearly on the concentration of the complex, indicating a first-order dependence on the catalyst concentration (Fig. 10).

\subsection{Antioxidant activity}

Oxidative stress induced due to the generation of free radicals and/or decreased antioxidant level in the target cells and tissues, has been suggested to play an important role in carcinogenesis. ${ }^{41}$ During cell membrane damage, various enzymes leak down to the circulatory fluid and their assessment in serum serves as markers in clinical studies. SOD is the first antioxidant enzyme to deal with oxy radicals by accelerating the dismutation of superoxide to hydrogen peroxide. Thus, SOD acts as supportive anti-oxidative enzyme, which provides protective defence against reactive oxygen species. ${ }^{42}$ Hepatic GSH-Rd and serum activities of SOD, and GSH-S-transferase levels were measured as an indicator for antioxidant activity. The results are presented in Table 5. SOD and GSH-Stransferase are antioxidant enzymes that protect cells from oxidative stress of highly reactive free radicals and induce the generation of free radicals in living cells. The results indicated that no significant deference was found between the used doses (200 and $400 \mathrm{mg} \mathrm{kg}^{-1}$ ) with all tested compounds. Compounds 1 and 3 were the highest in SOD and GST enzyme activities rather than GSH-Rd levels in comparison to the other 
Table 5 Effects of $\mathrm{Cu}($ II) complexes 1-4 on SOD, GSH-S-tranferase, and GSH-Rd levels

\begin{tabular}{|c|c|c|c|}
\hline Design of treatment & SOD (units per mg protein) & GST ( $\mu$ mol per mg protein) & GSH-Rd (mg per $\mathrm{g}$ protein) \\
\hline (1) $\left(200 \mathrm{mg} \mathrm{kg}^{-1}\right)$ (Group 2) & $59 \pm 1^{\mathrm{a}, \mathrm{b}}$ & $7.9 \pm 0.1^{\mathrm{a}, \mathrm{b}}$ & $6.8 \pm 0.5^{\mathrm{a}, \mathrm{b}}$ \\
\hline (2) $\left(200 \mathrm{mg} \mathrm{kg}^{-1}\right)$ (Group 4) & $42 \pm 2$ & $5.2 \pm 0.2$ & $4.2 \pm 0.9$ \\
\hline (2) $\left(400 \mathrm{mg} \mathrm{kg}^{-1}\right)$ (Group 5) & $42 \pm 1$ & $6.0 \pm 0.2$ & $4.6 \pm 0.2$ \\
\hline (3) $\left(200 \mathrm{mg} \mathrm{kg}^{-1}\right)$ (Group 6) & $61 \pm 3^{\mathrm{a}, \mathrm{b}}$ & $8.5 \pm 0.1^{\mathrm{a}, \mathrm{b}}$ & $7.6 \pm 0.1^{\mathrm{a}, \mathrm{b}}$ \\
\hline (3) $\left(400 \mathrm{mg} \mathrm{kg}^{-1}\right)$ (Group 7) & $58 \pm 1^{\mathrm{a}, \mathrm{b}}$ & $8.2 \pm 0.1^{\mathrm{a}, \mathrm{b}}$ & $6.4 \pm 0.1^{\mathrm{a}, \mathrm{b}}$ \\
\hline Vitamin E (100 mg/ kg) (Group 12) & $59 \pm 2$ & $6.9 \pm 0.1$ & $5.8 \pm 0.2$ \\
\hline
\end{tabular}

Values are mean $\pm \mathrm{SD}, n=5 .{ }^{\mathrm{a}, \mathrm{b}}$ The difference is significant $(p>0.05)$ in a column between treated and infected control group 2.

synthesized compounds. A major defence mechanism involves the antioxidant enzymes, including SOD, catalase and glutathione peroxidase (GPx), which convert active oxygen molecules into non-toxic compounds. Lipid peroxidation is accelerated when free radicals are formed as the result of losing a hydrogen atom from the double bond in the structure of unsaturated fatty acids.

\section{Conclusions}

A series of copper(II) complexes containing the tripodal 3,5-dimethylpyrazolyl (KTp $\left.{ }^{\mathrm{MeMe}}\right)$ ligand were synthesized and fully characterized. The kinetics and mechanism of ligand substitution by thiourea were studied in detail as a function of entering nucleophile concentration, temperature and pressure in methanol and acetonitrile as solvents. The kinetics showed that the substitution reaction of $\mathbf{1}$ is a biphasic process that involves the displacement of both solvent and chloride ligands. In methanol, the substitution of the solvent by TU is forty times faster than the substitution of chloride. The activation parameters for both substitution reactions support an interchange dissociative mechanism. When the substitution reaction was carried out in acetonitrile, the rate constant for the displacement of the solvent was more than 200 times faster than for the reaction in methanol, which is ascribed to the weaker donor properties of the solvent. In addition, the significantly more positive activation volumes found for both reaction steps in acetonitrile compared to methanol, favour a limiting dissociative substitution mechanism. The antioxidant activity of complexes 1-4 have been evaluated for SOD, GST0 and GSH-R levels. 1 and 2 were found to show $(p<0.05)$ the highest antioxidant activity in comparison to 3 and 4 , which can be ascribed to their structure. 1 has catechol oxidase activity with a turnover number of $20 \mathrm{~min}^{-1}$ and the coordination affinity of 3,5 -DTBC, $K_{1},=31 \mathrm{mM}^{-1} . K_{1}$ is rather large and seems to be typical for faster models and the enzyme itself $\left(25 \mathrm{mM}^{-1}\right)$. The reaction rate depends linearly on the concentration of the complex, indicating a first-order dependence on catalyst concentration. The question arises whether the geometry of the complexes has an influence on the cate- chol oxidase activity? To answer this, we are now performing more detailed studies that will be reported later.

\section{Experimental}

\subsection{Materials and general methods}

Caution! Perchlorate salts are potential explosives and only small quantities were handled with care. All chemicals used were of analytical grade. The solvent dimethyl sulfoxide (DMSO) and vitamin E were obtained from Sigma Chemical Co. (St. Louis, MO, USA). All enzymatic kits were purchased from Spinreact, Spain. The ligand potassium hydrotris(3,5-dimethylpyrazolyl)borate $\mathrm{KTp}^{\mathrm{MeMe} 43}$ and the $\mathrm{Cu}(\mathrm{II})$ complex $3^{20}$ were synthesized as reported in the literature. The elemental analysis of the ligand and its metal complexes were performed using a Perkin Elmer Series II CHNS/O Analyser 2400. Infrared spectra of the free ligand and its metal complexes were recorded using an Alpha-Attenuated FT-IR spectrophotometer, Bruker, in the range 400-4000 $\mathrm{cm}^{-1}$. Raman spectra were recorded on a Bruker FT-Raman spectrometer with laser. The conductivity measurements were carried out using an Equiptronics digital conductivity meter model JENWAY 4070 at room temperature for $1 \mathrm{mM}$ solutions. All UV-Vis measurements were recorded on a UV-Lambda 25 Perkin Elmer spectrophotometer. Magnetic moments were measured by Gouy's method at room temperature. EPR measurements of the polycrystalline samples at room temperature were made on a Varian E9 $\mathrm{X}$-band spectrometer using a quartz Dewar vessel. All spectra were calibrated against DPPH $(g=2.0027)$. The specific conductance of the complexes was measured using freshly prepared $(1 \mathrm{mM})$ solutions in water at room temperature using YSI Model 32 conductance meter. Thermal analyses of the complexes were recorded on a Netzsch STA 449F3 instrument with a system interface device in a nitrogen atmosphere. Molecular modelling calculations were done using computer program HyperChem version 8.0.

\subsection{Synthesis of the copper(II) complexes 1, 2 and 4}

$\mathrm{Cu}(\mathrm{II})$ complexes 1, 2 and 4 were prepared by mixing a methanolic solution of the ligand $\mathrm{KTp}^{\mathrm{MeMe}}$ with the corresponding 
copper(II) salts in a 1:1 molar ratio. A solution of $336 \mathrm{mg}$ $(1 \mathrm{mmol})$ of the ligand $\mathrm{KTp}^{\mathrm{MeMe}}$ in abs. $\mathrm{MeOH}(10 \mathrm{~mL})$ was added dropwise (30 min) to a solution of $1 \mathrm{mmol}$ of the corresponding $\mathrm{Cu}(\mathrm{II})$ salt dissolved in abs. $\mathrm{MeOH}(10 \mathrm{~mL})$. The resulting mixed solution was stirred for another $4 \mathrm{~h}$ at room temperature. The volume of the solution was reduced to $10 \mathrm{ml}$ in vacuum, the precipitate was filtered off, and the filtrate was evaporated to dryness. The residue was dissolved in $10 \mathrm{ml}$ of $\mathrm{CH}_{2} \mathrm{Cl}_{2}$, filtered, and evaporated to dryness again under vacuum over anhydrous $\mathrm{CaO}$.

4.2.1. $\left[\mathrm{Tp}^{\mathrm{MeMe}} \mathrm{Cu}(\mathbf{C l})\left(\mathrm{H}_{2} \mathrm{O}\right)\right]$ (1). Anal. For $\mathrm{C}_{15} \mathrm{H}_{24} \mathrm{BClCuN}_{6} \mathrm{O}$ (414.2): calcd C, 43.50; H, 5.84; N, 20.29; Cl, 8.56; Cu, 15.34. Found. C, 43.69; H, 5.72; N, 20.33; Cl, 8.49; Cu, 15.21. IR (KBr): $\nu\left(\mathrm{cm}^{-1}\right)$ : 3351 (br, w), $2922(\mathrm{w}), 2505$ (w, B-H), $1538(\mathrm{~m}), 1443$ (m), $1413(\mathrm{w}), 380(\mathrm{w}), 1363(\mathrm{~m}), 1200(\mathrm{~s}), 1185(\mathrm{~s}), 1063(\mathrm{w})$, $1034(\mathrm{w}), 979(\mathrm{w}), 865(\mathrm{w}), 844(\mathrm{w}), 805(\mathrm{w}), 766(\mathrm{~m}), 644(\mathrm{w})$, $469(\mathrm{w}), 454(\mathrm{w})$.

4.2.2. [T $\left.\mathrm{Tp}^{\mathrm{MeMe}} \mathrm{Cu}(\mathrm{OAc})\left(\mathrm{H}_{2} \mathrm{O}\right)\right]$ (2). Anal. For $\mathrm{C}_{17} \mathrm{H}_{27} \mathrm{BCuN}_{6} \mathrm{O}_{3}$ (437.8): calcd C, 46.64; H, 6.22; N, 19.20; Cu, 14.51. Found. C, 45.89; H, 6.10; N, 19.75; Cu, 14.62. IR (KBr): $\nu\left(\mathrm{cm}^{-1}\right): 3254$ (br, w), 2926 (w), 2506 (w, B-H), 1559 (s), 1398 (s), $1180(\mathrm{w}), 1045(\mathrm{w}), 1017(\mathrm{w}), 926(\mathrm{w}), 810(\mathrm{w}), 744(\mathrm{w}), 674$ $(\mathrm{w}), 644(\mathrm{w}), 620(\mathrm{w}), 468(\mathrm{w}), 431(\mathrm{w})$.

4.2.3. [Tp $\left.{ }^{\mathrm{MeMe}} \mathrm{Cu}\left(\mathrm{ClO}_{4}\right)\right]$ (4). Anal. For $\mathrm{C}_{15} \mathrm{H}_{24} \mathrm{BClCuN}_{6} \mathrm{O}_{4}$ (460.19): calcd C, 39.15; H, 4.82; N, 18.26; Cl, 7.70; Cu, 13.81. Found. C, 39.02; H, 4.69; N, 18.35; Cl, 7.58; Cu, 13.77. IR (KBr): $\nu\left(\mathrm{cm}^{-1}\right): 3501$ (br, w), $3334(\mathrm{w}), 2954(\mathrm{w}), 2507$ (w, B-H), 1639 (w), $1577(\mathrm{~m}), 1416(\mathrm{w}), 1095\left(\mathrm{~s}, \mathrm{ClO}_{4}{ }^{-}\right), 1044(\mathrm{~S}), 1023$ (s), 926 $(\mathrm{w}), 810(\mathrm{~m}), 674(\mathrm{w}), 623(\mathrm{w}), 576(\mathrm{w}), 476(\mathrm{w}), 429(\mathrm{w})$.

\subsection{Kinetic measurements}

UV-vis spectra were recorded on a Varian Cary 5G or Cary 1 spectrophotometer equipped with a thermostated cell holder or on a Shimadzu UV-2101-PC spectrophotometer with a thermoelectrically controlled cell holder for the determination of $\mathrm{p} K_{\mathrm{a}}$ values and for the study of slow reactions. Kinetic measurements on fast reactions were studied on an Applied Photophysics SX 18MV and KinetAsyst SF-61DX2 stopped-flow instrument coupled to an online data acquisition system. Experiments at elevated pressure were performed on a laboratory-made high pressure stopped-flow instrument for fast reactions. ${ }^{44}$ Spectral changes of the reactions were first recorded over the wavelength range $190-600 \mathrm{~nm}$ to establish a suitable wavelength at which the kinetic trace could be followed. The ligand substitution reactions were studied under pseudo first order conditions. This was achieved by using at least a 10 -fold excess of the nucleophile. All reported rate constants represent an average value of at least three independent kinetic runs for each experimental condition. The temperature dependence was studied in the range $6-28{ }^{\circ} \mathrm{C}$, and the pressure dependence was studied from 1 to $130 \mathrm{MPa}$.

\subsection{Biological and biochemical assays experiments}

4.4.1. Experimental animals. Male Albino mice $(20 \pm 2 \mathrm{~g})$ were obtained from the Department of Animal Science, Cairo University, and animals were handled under standard labora- tory conditions with a $12 \mathrm{~h}$ light/dark cycle at a temperature of $25 \pm 1{ }^{\circ} \mathrm{C}$ and a relative humidity of $55 \pm 5 \%$. The basal diet used in these studies was a certified feed to research laboratory animals. Food and water were available ad libitum. The Cairo University animal care and use committee approved all protocols for the animal research studies.

4.4.2. Bioassays experimental design. The animals were randomly divided into 12 experimental groups of 6 mice each. The first group served as normal control. Group 2 to 11 animals were treated with the synthesized compounds 1-4 at 200 and $400 \mathrm{mg}$ per $\mathrm{kg}$ weight per day, respectively, for 15 days. Group 12 animals were treated with standard drug Vitamin E (100 mg per $\mathrm{kg}$ weight per day) for 15 days. $24 \mathrm{~h}$ after the last administration, mice were sacrificed; blood samples were collected and centrifuged at $4000 \mathrm{~g}$ at $4{ }^{\circ} \mathrm{C}$ for $10 \mathrm{~min}$ for serum preparation. The liver was removed rapidly, washed and homogenized in ice-cold physiological saline to prepare $10 \%(\mathrm{w} / \mathrm{v})$ homogenate. Then, the homogenate was centrifuged at $4000 \mathrm{~g}$ at $4{ }^{\circ} \mathrm{C}$ for $10 \mathrm{~min}$ to remove cellular debris, and the supernatant was collected for biochemical analysis.

4.4.3. Measurement of glutathione- $S$-transferase (GST) activity. GST activity was determined as described by Habig et al., (1974). The reaction mixture containing $50 \mathrm{mM}$ phosphate buffer, $\mathrm{pH}$ 7.5, $1 \mathrm{mM}$ of 1-chloro-2,4-dinitrobenzene (CDNB) and appropriate volume of compound solution. The reaction was initiated by the addition of reduced glutathione (GSH) and formation of $S$-(2,4-dinitrophenyl)glutathione (DNP-GS) was monitored as an increase in absorbance at $334 \mathrm{~nm}$. The result was expressed as $\mu \mathrm{mol}$ of CDNB conjugation formed $/ \mathrm{mg}$ protein $/ \mathrm{min}$.

4.4.4. Measurement of super oxide dismutase (SOD) activity. SOD activity was measured through the inhibition of hydroxylamine oxidation by the superoxide radicals generated in the xanthine oxidase system. ${ }^{45}$ The results are expressed in units per mg protein.

4.4.5. Measurement of glutathione reduced (GSH-Rd) levels. The GSH-Rd level in liver tissue was determined according to the Ellman method, ${ }^{46}$ which measures the reduction of 5,5-dithio-bis(2-nitrobenzoic acid) (DTNB) (Ellman's reagent) by sulfhydryl groups to 2-nitro-5-mercaptobenzoic acid, which has an intense yellow colour. The results were expressed in $\mathrm{mg}$ per $\mathrm{g}$ protein ( $\mathrm{mg}$ per $\mathrm{g}$ protein).

4.4.6. Measurement of protein content. Protein levels were determined spectrophotometrically at $595 \mathrm{~nm}$, using comassie blue $\mathrm{G} 250$ as a protein binding dye. ${ }^{47}$ Bovine serum albumin (BSA) was used as a protein standard.

\subsection{Catecholase assays}

Catecholase activity was measured against 3,5-di-tert-butylcatechol (3,5-DTBC). Kinetic assays were conducted in methanol (saturated with 1 atm $\mathrm{O}_{2}$ ) at $298 \mathrm{~K}$ and formation of the product was monitored at $390 \mathrm{~nm}$. Under these conditions no formation of quinone was observed in the absence of the silicon complex. In substrate-dependent measurements, the concentration of complex was held constant at $0.5 \times 10^{-4} \mathrm{M}$, 
and the concentration of 3,5-DTBC was varied between 10 and $80 \mathrm{mM}$. For measurement of the complex dependence, the concentration of 3,5-DTBC was kept constant at $25 \mathrm{mM}$, and the concentration of the complexes was varied between 10 and $100 \mu \mathrm{M}$.

\section{Acknowledgements}

Financial support for this work from the Kafrelsheikh University, Egypt, and the Deutsche Forschungsgemeinschaft, Germany, is gratefully acknowledged.

\section{References}

1 (a) P. Guerriero, S. Tamburini and P. A. Vigato, Coord. Chem. Rev., 1995, 139, 17; (b) J. S. Yamada, Coord. Chem. Rev., 1999, 190-192, 537.

2 P. A. Vigato, S. Tamburini and D. E. Fenton, Coord. Chem. Rev., 1990, 106, 25.

3 V. McKee, M. Zvagulis, V. Dagdigian, M. C. Path and C. A. Reed, J. Am. Chem. Soc., 1984, 106, 4765.

4 (a) K. A. Magnus, H. Ton and J. E. Carpenter, Chem. Rev., 1994, 94, 727; (b) E. Solomon, M. J. Baldwin and M. D. Lowery, Chem. Rev., 1992, 92, 521.

5 (a) O. Hayaishi, Oxygenases, Academic Press, New York, 1962; (b) H. Sigel, Metal Ions in Proteins, Marcel Dekker, New York, 1981.

6 A. L. Hughes, Immunogenetics, 1999, 49, 106.

7 (a) C. Gerdemann, C. Eicken and B. Krebs, Acc. Chem. Res., 2002, 35, 183; (b) E. I. Solomon, U. M. Sundaram and T. E. Machonkin, Chem. Rev., 1996, 96, 2563.

8 B. J. Deverall, Nature, 1961, 189, 311.

9 H. J. Wahlert and M. J. Holland, Enzymes: Proteins that act as catalysts, Baruch College, http://faculty.baruch.cuny.edu/ jwahlert/bio1003/enzymes.html.

10 I. A. Koval, P. Gamez, C. Belle, K. Selmeczi and J. Reedijk, Chem. Soc. Rev., 2006, 35, 814.

11 (a) K. Selmeczi, M. Reglier, M. Giorgi and G. Speier, Coord. Chem. Rev., 2003, 245, 191; (b) H. Borzel, P. Comba and H. Pritzkow, Chem. Commun., 2001, 97; (c) E. Monzani, G. Battaini, A. Perotti, L. Casella, M. Gullotti, L. Santagostini, G. Nardin, L. Randaccio, S. Geremia, P. Zanello and G. Opromolla, Inorg. Chem., 1999, 38, 5359; (d) E. Monzani, L. Quinti, A. Perotti, L. Casella, M. Gullotti, L. Randaccio, S. Geremia, G. Nardin, P. Faleschini and G. Tabbi, Inorg. Chem., 1998, 37, 553.

12 (a) M. K. Panda, M. M. Shaikh, R. Butcher and P. Ghosh, Inorg. Chim. Acta, 2011, 372, 145; (b) G. Speier, J. Mol. Catal., 1986, 37, 259; (c) Z.-F. Chen, Z.-R. Liao, D.-F. Li, W.-K. Li and X.-G. Meng, J. Inorg. Biochem., 2004, 98, 1315.

13 (a) P. E. M. Siegbahn, J. Biol. Inorg. Chem., 2004, 9, 577; (b) C. Eicken, B. Krebs and J. C. Sacchettini, Curr. Opin. Struct. Biol., 1999, 9, 677; (c) T. R. Demmin, M. D. Swerdloff and M. M. Rogic, J. Am. Chem. Soc., 1981, 103, 5795.
14 A. Kupan, J. Kaizer, G. Speier, M. Giorgi, M. Reglier and F. Poll reisz, J. Inorg. Biochem., 2009, 103, 389.

15 (a) S. Y. Shaban, M. A. Ramadan and R. van Eldik, J. Coord. Chem., 2012, 65, 2415; (b) M. A. Ramadan, M. M. Ibrahim and I. M. El-Mehasseb, J. Coord. Chem., 2012, 65, 2256; (c) M. M. Ibrahim and S. Y. Shaban, Inorg. Chim. Acta, 2009, 362, 1471; M. A. Ramadan, M. M. Ibrahim and S. Y. Shaban, J. Mol. Struct., 2011, 1006, 348.

16 (a) N. Kitajima, K. Fujisawa and Y. Moro-oka, J. Am. Chem. Soc., 1990, 112, 3210; (b) J. S. Thompson, J. L. Zitzmann, T. J. Marks and J. A. Ibers, Inorg. Chim. Acta, 1980, 46, 101; (c) J. S. Thompson, T. J. Marks and J. A. Ibers, Proc. Natl. Acad. Sci. U. S. A., 1977, 74, 3114; (d) J. S. Thompson, T. J. Marks and J. A. Ibers, J. Am. Chem. Soc., 1979, 101, 4180.

17 (a) S. Trofimenko, Scorpionates - The Coordination Chemistry of Polypyrazolylborate Ligands, Imperial College Press, London, 1999; (b) N. Kitajima and W. B. Tolman, Prog. Inorg. Chem., 1995, 43, 419; (c) G. Parkin, Chem. Commun., 2000, 1971.

18 (a) N. Kitajima, K. Fujisawa and Y. Moro-oka, J. Am. Chem. Soc., 1992, 114, 9232; (b) K. Fujisawa, K. Fujita, T. Takahashi, N. Kitajima, Y. Moro-oka, Y. Matsunaga, Y. Miyashita and K. Okamoto, Inorg. Chem. Commun., 2004, 7, 1188; (c) Y. Matsunaga, K. Fujisawa, N. Ibi, Y. Miyashita and K. Okamoto, Inorg. Chem., 2005, 44, 325.

19 D. J. Harding, W. Phonsri, P. Harding, J. Sirirak, Y. Tangtirungrotechai, R. D. Webster and H. Adams, New J. Chem., 2015, 39, 1498-1505.

20 (a) K. Fujisawa, T. Kobayashi, K. Fujita, N. Kitajima, Y. Moro-oka, Y. Miyashita, Y. Yamada and K. Okamoto, Bull. Chem. Soc. Jpn., 2000, 73, 1797; (b) K. Fujisawa, Y. Miyashita, Y. Yamada and K.-I. Okamoto, Bull. Chem. Soc. Jpn., 2001, 74, 1065-1066.

21 S. Trofimenko, J. C. Calabrese and J. S. Thompson, Inorg. Chem., 1987, 26, 1507.

22 W. J. Geary, Coord. Chem. Rev., 1971, 7, 81.

23 S. Trofimenko, J. Am. Chem. Soc., 1969, 91, 3183.

24 R. M. Silverstein, G. C. Bassler and T. C. Morrill, Spectrometric Identification of Organic Compounds, New York, 4th edn, 1981.

25 D. A. Baldwin, A. B. P. Lever and R. V. Parish, Inorg. Chem., 1971, 10, 4755.

26 K. Nakamoto, Infrared Spectra of Inorganic and Coordination Compounds, J. Wiley and Sons, New York, 1986, p. 256.

27 O. O. E. Onawumi, O. O. P. Faboya, O. A. Odunola, T. K. Prasad and M. V. Pajasekharan, Polyhedron, 2008, 27, 113.

28 (a) R. N. Patel, N. Singh, D. K. Patel and V. L. N. Gundla, Indian J. Chem., 2007, 46A, 422; (b) N. M. El-Metwaly, I. M. Gabr and A. A. El-Asmy, Transition Met. Chem., 2006, 31, 71 .

29 L. M. L. Chia, S. Radojevic, I. J. Scowen, M. McPartlin and M. A. Halcrow, J. Chem. Soc., Dalton Trans., 2000, 133.

30 R. L. Dutta and A. Syamal, Elements of Magnetochemistry, Affiliated East-West Press, New Delhi, 1st edn, 2007.

31 B. J. Hathaway and O. E. Billing, Coord. Chem. Rev., 1970, 5, 143. 
32 I. M. Procter, B. J. Hathaway and P. Nicholls, J. Chem. Soc. A, 1969, 1678.

33 K. Fujisawa, Y. Miyashita, Y. Yamada and K. Okamoto, Bull. Chem. Soc. Jpn., 2001, 74, 1065.

34 A. W. Coats and J. P. Redfern, Nature, 1964, 201, 68.

35 T. Hatakeyama and Z. Liu, Handbook of Thermal Analysis, Wiely, Chichester, UK, 1998.

36 S. Y. Shaban, F. W. Heinemann and R. van Eldik, Eur. J. Inorg. Chem., 2009, 3111.

37 (a) R. van Eldik, Coord. Chem. Rev., 2007, 251, 1649; (b) J. Burgess, Metal Ions in Solution, Ellis Horwood, Chichester, 1978; (c) C. H. Langford and H. B. Gray, Ligand Substitution Processes, W. A. Benjamin Inc., New York and Amsterdam, 1965, p. 8; (d) T. W. Swaddle, Coord. Chem. Rev., 1974, 14, 217.

38 L. Helm and A. E. Merbach, Chem. Rev., 2005, 105, 1923.

39 (a) S. F. Lincoln, A. M. Hounslow, D. L. Pisaniello, B. G. Doddridge, J. H. Coates, A. E. Merbach and
D. Zbinden, Inorg. Chem., 1984, 23, 1090; (b) S. F. Lincoln, A. M. Hounslow, B. G. Doddridge and J. H. Coates, Inorg. Chim. Acta, 1985, 100, 207.

40 S. J. Smith, C. J. Noble, R. C. Palmer, G. R. Hanson, G. Schenk, L. R. Gahan and M. J. Riley, J. Biol. Inorg. Chem., 2008, 13, 499.

41 Y. L. Huang, J. Y. Heu and T. H. Lin, Clin. Biochem., 1999, $32,31$.

42 C. J. Weydert, T. A. Waugh, J. M. Ritchie, K. S. Iyer, J. L. Smith, L. Li, D. R. Spitz and L. W. Oberley, Free Radicals Biol. Med., 2006, 41, 226.

43 G. Parkin, Chem. Rev., 2004, 104, 699.

44 R. van Eldik, W. Gaede, S. Wieland, J. Kraft, M. Spitzer and D. A. Palmer, Rev. Sci. Instrum., 1993, 64, 1355.

45 B. Das Kakkar and P. N. Visvanathan, Indian J. Biochem. Biophys., 1972, 197, 588.

46 G. L. Ellaman, Arch. Biochem. Biophys., 1959, 82, 70.

47 M. M. Bradford, Anal. Biochem., 1976, 72, 248. 